\title{
The Effect of Erythropoiesis-Stimulating Agents on Platelet Aggregation in Peritoneal Dialysis Patients
}

\author{
Periton Diyaliz Hastalarında Eritropoietin Stimüle Eden Ajanlar Kullanımının \\ Trombosit Agregasyonu Üzerindeki Etkisi \\ (D) Serkan Bakırdöğen11, (10 Necmi Eren², (1) Sibel Gökçay Bek², (D) Sara Yavuz³ \\ ${ }^{1}$ Çanakkale Onsekiz Mart University Faculty of Medicine, Department of Internal Medicine, Division of Nephrology, Çanakkale, Turkey \\ ${ }^{2}$ Kocaeli University Faculty of Medicine, Medicine Department of Internal Medicine, Division of Nephrology, Kocaeli, Turkey \\ 3Yeditepe University Faculty of Medicine, Department of Internal Medicine, Division of Nephrology, İstanbul, Turkey
}

\begin{abstract}
Introduction: Erythropoietin (Epo) is a hormone that is synthesized in the kidneys and that stimulates the erythropoiesis in the bone marrow. Epo has effects apart from the erythropoiesis. In chronic renal failure (CRF) patients, hemorrhagic diathesis is observed, and Epo production is decreased. Erythropoiesis-stimulating agents (ESAs) are widely used in the treatment of renal anemia in these patients. Our study aimed to investigate the effect of ESAs use on platelet aggregation in peritoneal dialysis (PD) patients due to CRF.
\end{abstract}

Methods: Forty-three PD patients were included in the study. Seventeen patients had been using ESAs for anemia for at least three months (ESAs user group). Twenty-six patients were not using ESAs since they did not have indications (nonESAs user group). Platelet aggregation measurement from the whole blood was carried out in each patient by a multiplate device. The calculated values [area under the curve (AUC), aggregation, and velocity] were recorded. The results were evaluated statistically, and $p<0.05$ was accepted as statistically significant.

Results: In the non-ESAs user group, the mean hemoglobin level was found higher when compared to the other group, and this difference was statistically significant $(p<0.001)$. The percentage of transferrin saturation was found higher in the ESAs user group $(p=0.021)$. It was observed that AUC, aggregation, and velocity values were lower in the ESAs user group, and the result was not statistically significant ( $p$ values were $0.202,0.329,0.290$, respectively).

Conclusion: ESAs use in PD patients did not have any effect on platelet aggregation. Further prospective studies involving platelet aggregation tests before and after ESA treatment in dialysis patients are needed.

Keywords: Platelet aggregation, erythropoiesis-stimulating agents, peritoneal dialysis

\section{öZ}

Amaç: Eritropoietin (Epo), böbrekler tarafından sentez edilen ve kemik iliğinde eritropoezi uyaran bir hormondur. Epo hormonunun eritropoez dışında etkileri de mevcuttur. Kronik böbrek yetmezliği (KBY) hastalarında kanama diyatezi görülür ve Epo üretimi azalmıştır. Bu hastalarda renal aneminin tedavisinde eritropoietin stimüle eden ajanların (ESAs) kullanımı yaygındır. Çalışmamızın amacı; KBY nedeniyle periton diyalizi (PD) uygulayan hastalarda, ESAs kullanımının trombosit agregasyonu üzerindeki etkisini araştırmaktı.

Yöntemler: Çalıșmaya 43 PD hastası dahil edildi. En az üç ay süreyle ve anemi nedeniyle ESAs kullanımı olan 17 hasta mevcuttu (ESAs kullanan grup). Endikasyonu olmadığından 26 hasta ESAs kullanmıyordu (ESAs kullanmayan grup). Multiplate cihazı ile her hastanın tam kandan trombosit agregasyon ölçümü yapıldı. Hesaplanan değerler [eğrinin altında kolon olan (AUC) agregasyon ve velozite] kaydedildi. Sonuçlar istatistiksel olarak değerlendirildi. $\mathrm{P}<0.05$ istatistiksel anlamlı kabul edildi.

Bulgular: ESAs kullanmayan grupta, diğer gruba kıyasla ortalama hemoglobin seviyesi daha yüksek bulundu ve bu farklılık istatistiksel anlamlıydı $(p<0,001)$. Ortalama transferrin satürasyonu, ESAs kullanan grupta, diğer gruba göre daha yüksek saptandı ( $p=0,021)$. ESAs kullanan grupta, diğer gruba kıyasla AUC, agregasyon ve velozite değerlerinin daha düșük olduğu görüldü; sonuç istatistiksel anlamlı değildi ( $p$ değerleri sirasıyla 0,$202 ; 0,329 ; 0,290$ ).

Sonuç: PD hastalarında ESAs kullanımının trombosit agregasyonu üzerine etkisi yoktu. Diyaliz hastalarında ESAs tedavisinden önce ve sonra trombosit agregasyon testlerinin yapıldığı ileriye dönük çalıșmalara ihtiyaç vardır.

Anahtar Kelimeler: Trombosit agregasyonu, eritropoietin sitümüle eden ajanlar, periton diyalizi 


\section{Introduction}

Erythropoietin (Epo) is a hormone that is synthesized in the kidneys, which provides the continuity of erythropoiesis by protecting the erythrocytic precursors colony-forming unit-erythroid, and burstforming unit-erythroid cells against the apoptosis (1). Epo hormone has some effects apart from the erythropoiesis. It can provide regeneration both on muscular tonus and on gonadal and cognitive functions with its anti-apoptotic feature, as well as its autocrine, paracrine, and endocrine effects (2).

Chronic renal failure (CRF) disrupts the adhesion and aggregation of platelets with the extended bleeding time (3). Vascular erythrocytes drag platelets towards the vessel wall and increase their contact with each other. Also, they both perform the secretion of adenosine diphosphate (ADP) and the inactivation of prostacyclin. Using the erythropoiesisstimulating agents (ESAs) in patients with CRF may improve the functions of the platelet through increasing the hematocrit (4). Thrombotic complications in uremia are due to increased platelet aggregation and hypercoagulopathy (5). Long-term ESAs treatment increased the level of platelet cytosolic calcium that is stimulated by the thrombin from low to normal, independent from the hematocrit and blood pressure values in the rats of which CRF was created (3). It was determined that in experimental animals of which high doses of Epo were given in the short-term, platelet aggregation was increased, and the level of plasma soluble p-selectin was increased (6). Our study aimed to investigate the effect of ESAs use on platelet aggregation in peritoneal dialysis (PD) patients due to CRF.

\section{Methods}

\section{Patients Selection Evaluation}

Forty-three patients (22 females, 21 males) who are in the standard PD program (continuous ambulatory or automated peritoneal dialysis) were included in the study. The patients were randomly selected from the outpatient nephrology clinic of Kocaeli University Faculty of Medicine between the years 2011-2012.

The inclusion criteria of the study were volunteering, being 18 to 80 years old, and receiving PD at least for three months. The exclusion criteria were determined as; possessing diabetes mellitus, thrombocyte adhesion or aggregation defects, using aspirin or NSAI drugs in the last two weeks, or undergoing an infectious disease.

Committee approval was obtained for the study from Kocaeli University Ethics Committee (decision no: 2011/64, date: 27.06.2011). Informed consent was obtained.

A certain amount of blood was drawn from each patient who consulted to nephrology outpatient clinic for routine biochemical markers, following fasting of at least eight hours, and the results were assessed in the laboratory. The samples, which were drawn from each patient for exact blood count, were put into tubes that contain ethylenediaminetetraacetic acid, were analyzed in Cell-Dyn 3700 (Abbott Laboratories, Philippines), which operates with combined impedance and Multi-Angle Polarized Scatter Separation flow cytometry method. Percentage of transferrin saturation (100 x serum iron/TIBC) was studied with Abbott architect original kit. Seventeen PD patients with anemia (ESAs users) were using recombinant human erythropoietin (rHuEpo) by subcutaneous route for more than three months and with a dosage of $75-150 \mathrm{IU} / \mathrm{kg} /$ week and since there was not any indication, rHuEpo treatment was not performed on 26 PD patients (non-ESAs users).

\section{Platelet Aggregation Study}

The platelet aggregation values of each patient were recorded by measuring them in Multiplate (Dynabyte medical, Munich, Germany) device with multiple electrode aggregometry methods that can carry out measurements from whole blood. The increasing impedance due to platelets that adhere to the sensor of the device is transformed into aggregation unit (AU), and it is printed as a graph against time. Three values are calculated regarding platelet aggregation:

a) The area under the curve (AUC): Its unit is AU x minute,

b) Aggregation: Its unit is $\mathrm{AU}$,

c) Velocity: Its unit is AU/minute.

Whole blood, which was drawn from each patient into a hirudin blood tube, was studied in the laboratory with a multiplate device between 30 and 120 minutes. Three hundred $\mu$ of blood was taken into a hirudin blood tube and inserted in the test cell, and after a threeminute incubation by adding $300 \mu$ isotonic $\mathrm{NaCl}$, platelet aggregation measurement was carried out by adding $31 \mu \mathrm{l}(10 \mu \mathrm{mol} / \mathrm{L})$ ADP.

\section{Statistical Analysis}

SPSS 15.0 version was used for the statistical analysis of the study. The significance measurement between the groups of PD patient (ESAs users and non-ESAs users) was conducted with independent samples t-test for markers which comply with a normal distribution. Mann-Whitney U test was used for the variables that do not comply with a normal distribution. In the subgroup of patients, the chi-square test was used to analyze the gender parameter. $\mathrm{P}<0.05$ was accepted as statistically significant.

\section{Results}

According to the CRF etiology, 23 of the patients had hypertension, 11 of them had chronic glomerulonephritis, three of them had autosomal dominant polycystic kidney disease, one of them had amyloidosis, one of them had obstructive nephropathy, and four of them had idiopathic etiology. According to the outpatient clinic controls for the last three months, the patients were separated into two groups, ESAs users $(n=17)$ and non-ESAs users $(n=26)$. There was a statistically significant difference between the two groups in terms of age and gender parameters ( $p$ values were $0.001,0.012$, respectively). Biochemical data and demographic findings of PD patients were given in Table 1.

The mean hemoglobin level was found higher in the non-ESAs user group when compared to the other group, and this difference was statistically significant $(p<0.001)$. The percentage of transferrin saturation was detected higher in the ESAs user group when compared to the other group ( $p=0.021)$. Platelet aggregation values of ESAs user and not-ESAs user PD patients were compared in terms of AUC, aggregation, and velocity. It was observed that $\mathrm{AUC}$, aggregation, and velocity values were 
lower in the ESAs user group. The results were not statistically significant ( $p$ values were $0.202,0.329,0.290$, respectively). Platelet aggregation values of PD patients were presented in Table 2 .

\section{Discussion}

In our study, we have investigated the effect of ESAs use on platelet aggregation in PD patients. However, aggregation values in the ESAs user group were not statistically significant, and they were lower than the other group. Also, hemoglobin level was lower in patients who were using ESAs. Furthermore, the percentage of transferrin saturation was higher in the ESAs user group. This is probably because of ESAs use in anemic patients despite normal transferrin saturation (>20\%).

ESAs treatment in the experimental CRF model demonstrated the increase of platelet cytosolic calcium level (3). Although there are contradictory results in recent studies, ESAs treatment was also effective in platelet aggregation by increasing hemoglobin and hematocrit. Increased hematocrit may improve platelet function (4). Also, an inverse relationship was determined between platelet aggregation and the level of hemoglobin in hemodialysis (HD) patients. In the same study, an inverse relationship was found between platelet aggregation and the level of serum Epo in HD patients who were not given recombinant (rHuEpo) (7). An inverse relationship was reported between platelet aggregation and hematocrit in patients who are under the aspirin treatment and have coronary artery disease (8). There was not a relationship between platelet aggregation and hematocrit in healthy patients after the corrections were made regarding their age and gender (9).

In the study of Taylor et al. (10), ESAs user and non-ESAs user dialysis patients were compared to each other in terms of platelet aggregation. The study results pointed that platelet aggregation values changed and increased with ESAs treatment both in HD and PD patients, but in another study, ESAs treatment had not any effect on platelet aggregation and activation in continuous ambulatory PD patients (11).

In our study, the number of female patients was higher than male patients in ESAs user group, and the mean age of them was lower than the non-ESAs user group. Platelets of healthy women have both increased aggregation and activation potential (12). However, rHuEpo increased platelet aggregation induced by ADP in both male and female donors in a study of healthy and young individuals. Unlike women, a lower rHuEpo dose was used for effective platelet aggregation in men (13). Both thrombotic events and hospital mortality rates increased with age (14). In a study by Verdoia et al. (15), the mean values of the ADP test were higher in the elderly than patients under the age of seventy. However, no association was found between platelet aggregation and age in healthy individuals (9). In our study, subjects were randomly selected while forming the groups. Age and gender homogenization could not be achieved between the groups. Therefore, it may be challenging to interpret the available data.

There are some limitations in the study design. HD patients were not included in the study, and a control group of healthy volunteers could

\section{Table 1. Biochemical data and demographic findings of PD patients}

\begin{tabular}{|l|l|l|l|}
\hline & $\begin{array}{l}\text { ESAs user group }(\mathbf{n}=17) \\
\text { Mean } \pm \text { standard deviation }\end{array}$ & $\begin{array}{l}\text { Non-ESAs user group }(\mathbf{n}=\mathbf{2 6}) \\
\text { Mean } \pm \text { standard deviation }\end{array}$ & p \\
\hline Age (year) & $41 \pm 9.2$ & $52.7 \pm 9.9$ & 0.001 \\
\hline Gender (female) & 13 & 9 & 0.012 \\
\hline Dialysis duration (month) & $41.7 \pm 22.1$ & $40 \pm 23.5$ & 0.823 \\
\hline Total Kt/V (week) & $2.2 \pm 0.9$ & $2.4 \pm 0.9$ & 0.35 \\
\hline Hemoglobin (g/dL) & $9.3 \pm 1.3$ & $11.3 \pm 1.8$ & $<0.001$ \\
\hline Leukocyte (mm $)$ & $6898 \pm 1949$ & $7253 \pm 1683$ & 0.529 \\
\hline Platelet (mm $)$ & $235430 \pm 72800$ & $266690 \pm 71450$ & 0.258 \\
\hline Serum CRP (mg/dL) & $0.5 \pm 0.4$ & $1 \pm 0.9$ & 0.168 \\
\hline Serum albumin (g/dL) & $3.4 \pm 0.4$ & $3.5 \pm 0.3$ & 0.359 \\
\hline Serum ferritin (ng/mL) & $797 \pm 620$ & $479 \pm 352$ & 0.15 \\
\hline Transferrin saturation (\%) & $38.9 \pm 16.9$ & $28.6 \pm 10.8$ \\
\hline Systolic blood pressure (mmHg) & $151 \pm 20$ & $142 \pm 21$ & 0.021 \\
\hline Diastolic blood pressure (mmHg) & $89 \pm 13$ & $86 \pm 13$ & 0.153 \\
\hline PD: peritoneal dialysis, ESAs: erythropoiesis-stimulating agents, CRP: C-reactive protein & & 0.342 \\
\hline
\end{tabular}

Table 2. Platelet aggregation values of PD patients

\begin{tabular}{|l|l|l|}
\hline Platelet aggregation values & $\begin{array}{l}\text { ESAs user group }(\mathbf{n = 1 7}) \text { Mean } \pm \text { standard } \\
\text { deviation }\end{array}$ & $\begin{array}{l}\text { Non-ESAs user group (n=26) Mean } \pm \text { standard } \\
\text { deviation }\end{array}$ \\
\hline AUC (AUxminute) & $646.2 \pm 301.3$ & $748.3 \pm 215.1$ \\
\hline Aggregation (AU) & $121.4 \pm 63.4$ & $136.7 \pm 38.3$ \\
\hline Velocity (AU/minute) & $14.5 \pm 6.2$ & $16.4 \pm 5.6$ \\
\hline PD: peritoneal dialysis, AUC: area under the curve ESAs: erythropoiesis-stimulating agents AU: aggregation unit & 0.202 \\
\hline
\end{tabular}


not be formed. Our study is cross-sectional and observational, and platelet aggregation measurement was carried out by separating in PD patients into two groups as using ESAs for at least three weeks and the non-ESAs users. The basal platelet aggregation values of patients before ESAs treatment were not studied. Furthermore, serum Epo levels could not be determined additionally.

\section{Conclusion}

As a result, ESAs use in PD patients did not have any effect on platelet aggregation. Rather than ESAs use, serum hemoglobin levels may be more effective on platelet aggregation in patients. Further prospective studies involving platelet aggregation tests before and after ESAs treatment in PD patients are needed.

Ethics Committee Approval: Committee approval was obtained for the study from Kocaeli University Ethics Committee (decision no: 2011/64, date: 27.06.2011).

Informed Consent: Informed consent was obtained.

Peer-review: Externally peer-reviewed.

Author Contributions: Surgical and Medical Practices - S.B., N.E., S.G.B., S.Y.; Concept - S.B., N.E.; Design - S.B., N.E., S.Y.; Data Collection and/or Processing - S.B., S.G.B.; Analysis and/or Interpretation - S.B., N.E., S.G.B., S.Y.; Literature Search - S.B., N.E., S.G.B.; Writing Manuscript - S.B., N.E., S.G.B., S.Y.

Conflict of Interest: No conflict of interest was declared by the authors.

Financial Disclosure: The authors declared that this study received no financial support.

\section{References}

1. Jelkmann W. Molecular biology of erythropoietin. Intern Med 2004; 43: 64959.

2. Lappin TR, Maxwell AP, Johnston PG. EPO's alter ego: erythropoietin has multiple actions. Stem Cells 2002; 20: 485-92.

3. Zhou XJ, Vaziri ND. Defective calcium signaling in ureamic platelets and its amelioration with long-term erythropoietin therapy. Nephrol Dial Transplant 2002; 17: 992-7.
4. Hörl WH. Other Blood and Immune Disorders in Chronic Kidney Disease. Floege J, Johnson RJ, Feehally J, editors. Comprehensive Clinical Nephrology Fourth Edition. St.Louis, Missouri: Elsevier Saunders; 2010.p.959-68.

5. Hörl WH. [Thrombocytopathy and blood complications in uremia]. Wien Klin Wochenschr 2006; 118: 134-50.

6. Kirkeby A, Torup L, Bochsen L, Kjalke M, Abel K, Theilgaard-Monch K, et al. High-dose erythropoietin alters platelet reactivity and bleeding time in rodents in contrast to the neuroprotective variant carbamyl-erythropoietin (CEPO). Thromb Haemost 2008; 99: 720-8.

7. Borawski J, Pawlak K, Mysliwiec M. Inflammatory markers and platelet aggregation tests as predictors of hemoglobin and endogenous erythropoietin levels in hemodialysis patients. Nephron 2002; 91: 671-81.

8. Würtz M, Hvas AM, Kristensen SD, Grove EL. Platelet aggregation is dependent on platelet count in patients with coronary disease. Thromb Res 2012; 129 56-61.

9. Rubak P, Villadsen K, Hvas AM. Reference intervals for platelet aggregation assessed by multiple electrode platelet aggregometry. Thromb Res 2012; 130 420-3.

10. Taylor JE, Henderson IS, Stewart WK, Belch JJ. Platelet aggregation in erythropoietin treated dialysis patients. Platelets 1992; 3: 47-52.

11. Malyszko J, Suchowierska E, Pawlak K, Malyszko JS, Mysliwiec M. [Platelet aggregation and P-selectin concentration in patients on peritoneal dialysis treatedwith erythropoietin]. Pol Arch Med Wewn 2001; 105: 197-201.

12. Coleman JR, Moore EE, Kelher MR, Samuels JM, Cohen MJ, Sauaia A, et al. Female platelets have distinct functional activity compared to male platelets: Implications in transfusion practice and treatment of trauma-induced coagulopathy. J Trauma Acute Care Surg 2019; 87: 1052-60.

13. Gambardella L, Vona R, Pichini S, Pacifici R, Malorni W, Straface E. Gender difference in platelet aggregation and reactivity induced by recombinant human erythropoietin. Br J Clin Pharmacol 2016; 81: 789-91.

14. Avezum A, Makdisse M, Spencer F, Gore JM, Fox KA, Montalescot G, et al. Impact of age on management and outcome of acute coronary syndrome: observations from the Global Registry of Acute Coronary Events (GRACE). Am Heart J 2005; 149: 67-73.

15. Verdoia M, Pergolini P, Rolla R, Nardin M, Schaffer A, Barbieri L. Advanced age and high-residual platelet reactivity in patients receiving dual antiplatelet therapy with clopidogrel or ticagrelor. J Thromb Haemost 2016; 14: 57-64. 